\title{
A thermodynamic analysis of chloride corrosion in biomass-fired boilers for $\mathrm{Fe}-\mathrm{O}-\mathrm{Cl}-\mathrm{S}$ system
}

\author{
Robert Kaczmarczyk ${ }^{1,{ }^{*}}$, Agata Mlonka-Mędrala ${ }^{1}$, and Sebastian Gurgul ${ }^{2}$ \\ ${ }^{1}$ AGH University of Science and Technology, Faculty of Energy and Fuel, 30059 Krakow \\ Mickiewicza 30, Poland \\ ${ }^{2}$ MTU Aero Engines Polska Sp. z o.o., 36002 Jasionka Tajecina 108, Poland
}

\begin{abstract}
The paper presents a thermodynamic analysis of chlorideinduced corrosion in the Fe-O-Cl-S system. The influence of steam concentration in the gas phase on chloride-induced corrosion process was presented. Based on the parametric equations the equilibrium concentration of the gas phase was determined. The effect of alkali metals chlorides in gas phase $(\mathrm{Na}, \mathrm{K}) \mathrm{Cl}$ on formation of $(\mathrm{Na}, \mathrm{K}) \mathrm{FeO}_{2}$ in the passive oxide scale layer $\left(\mathrm{FeO} / \mathrm{Fe}_{3} \mathrm{O}_{4} / \mathrm{Fe}_{2} \mathrm{O}_{3}\right)$ was analysed. Condensation of $(\mathrm{Na}, \mathrm{K}) \mathrm{Cl}$ vapors, formation of low-melting eutectic mixtures in deposits and consequences of this process on corrosion process were examined. Additionally, the role of $\mathrm{SO}_{2}$ in chlorination and oxidation process of steel in melted ash deposits was discussed as well. The results were correlated with available in the literature laboratory experimental data and industrial corrosion process observations. Presented thermodynamic analysis was compared with assumptions of an "active oxidation" model. The results may be used for experimental research planning and a corrosion process prevention in the industry.
\end{abstract}

\section{Chloride-induced high temperature corrosion process of steel}

The emission limits for fossil fuel combusting units affects significantly the final product cost. [1,2]. Direct biomass combustion is the best alternative technology for fossil fuel combustion. The development of renewable energy sources is one of the priorities of Energy Policy until 2030. However, a limited material strength and corrosion resistance of boiler heat exchanging surfaces at higher temperatures is a major problem associated with biomass combustion and waste incineration. Flue gas and fly ash composition, combustion process parameters (especially flue gas and tube wall temperature), thermal gradient in the deposits and corrosive agent concentration in a wall boundary layer affect the corrosion process mechanism and kinetics. [3,4,5]. Corrosive species concentration in biomass firing units presents as follows: $25-1000 \mathrm{ppm} \mathrm{HCl}, 0-50 \mathrm{ppm}(\mathrm{K}, \mathrm{Na}) \mathrm{Cl}, 0-70 \mathrm{ppm} \mathrm{SO}_{2}$ [3]. Moisture content in the combustion gas is around $10-20 \%$. A passive oxide scale formed during boiler operation is composed of iron oxides. The rate of oxide scale formation in $\mathrm{Fe}-\mathrm{O}$ system is rather slow and it depends on a steel grade. In the gas phase, the oxygen concentration does not affect the kinetics of the process. [6,7]. The acceleration of steel degradation process by gaseous $\mathrm{HCl}$ in the exhaust gas was observed in numerous laboratory experiments and field

*Corresponding author: robertk@agh.edu.pl 
measurements. During biomass combustion chlorine is present mainly as $\mathrm{HCl}$ [8]. A socalled active oxidation model describes the steel oxidation process accelerated by chlorine in the exhaust gas. The model is widely described in the literature $[9,10]$. The fundamental assumptions of the ,active oxidation model" are presented in [9]. The high temperature corrosion experiments in a lab-scale ware carried out in simulated atmosphere $\mathrm{He}-\left[\mathrm{O}_{2}-\mathrm{HCl}-\right.$ $\left.\mathrm{SO}_{2}\right]$ and with fly ash deposits $\left(\mathrm{K}_{2} \mathrm{SO}_{4}, \mathrm{CaSO}_{4},(\mathrm{~K}, \mathrm{Na}) \mathrm{Cl}\right)$. The diffusion of $\mathrm{Cl}_{2}$ through the pores and cracks of the metal oxide scale, formation of $\mathrm{FeCl}_{2}(\mathrm{~g})$, which penetrates the scale backward to flue gas and final oxidation form a closed cycle of reactions. Such repeatability causes a severe oxide scale destruction and steel protective properties against chloride corrosion are lost. (Fig. 1)

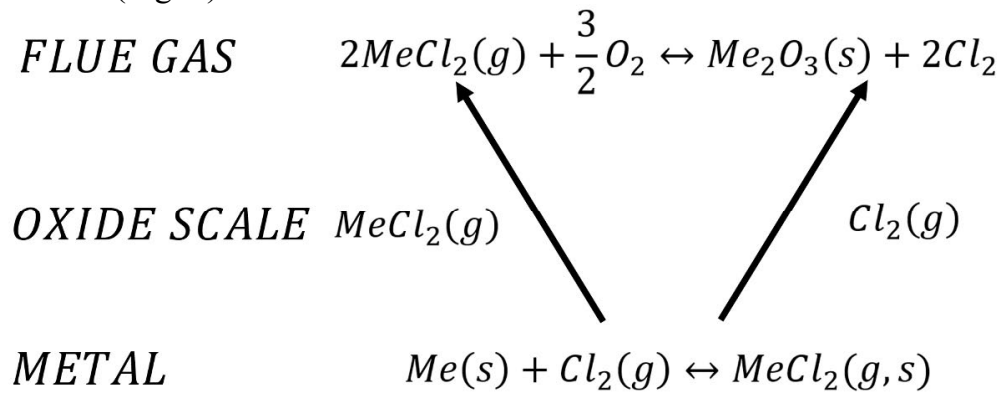

Fig. $1 \mathrm{Cl}$-induced corrosion cycle described in [9].

A steel oxidation process accelerated by chlorine presence in the flue gas called active oxidation is a possible mechanism of chlorine-induced corrosion process. However, the selectivity of oxide scale layer $\mathrm{Fe}_{3} \mathrm{O}_{4} / \mathrm{Fe}_{2} \mathrm{O}_{3}$ in diffusion process of gas phase components and neglecting of the other gas phase components influence (e.g. $\left.\mathrm{H}_{2} \mathrm{O}\right)$ on corrosion process rises some doubts among scientists. At high temperature, in reducing atmosphere rich in $\mathrm{HCl}$, the reaction of iron and hydrochloric acid in ash deposits layer was described in [11]. In $[6,12-15]$ the high temperature corrosion process was observed in oxidizing conditions $(5 \%$ $\mathrm{O}_{2}$ ) with 500-3000 ppm $\mathrm{HCl}$ and the metal chlorides were formed according to an active oxidation mechanism. In [5] the corrosion process was analysed under solid chlorides mixtures: $\mathrm{KCl}-\mathrm{ZnCl}_{2}$ in an oxidizing atmosphere $\left(\mathrm{Ar}-\mathrm{O}_{2}\right)$. A so-called hot corrosion process was examined in [16-19]. The influence of sulfur dioxide on the corrosion process was analysed in [3,9,20-25]. The reaction of sulfur dioxide with alkali chlorides deposited on heat exchanging surfaces is an additional source of molecular chlorine. [9] The melting temperature of the sulfates $\left(\mathrm{K}_{2} \mathrm{SO}_{4}-1347 \mathrm{~K}, \mathrm{Na}_{2} \mathrm{SO}_{4}-1157 \mathrm{~K}\right)$ is lower than the heat exchanger wall temperature. Therefore, the alkali sulfates in the fly ash deposits are less corrosive than the chlorides. For molar ratio $\mathrm{S} / \mathrm{Cl}>2-2,2$ the chlorine-induced corrosion is no longer a problem [20]. In [24,25] the free alkali index was determined based on elementary analysis of the selected fuels. Free alkali metals (not bounded by the $\mathrm{Cl}$ and $\mathrm{S}$ in the fuel) will form alkali metal hydroxides. [24] $\mathrm{KOH}$ and $\mathrm{NaOH}$ seems to be more corrosive than other compounds (sulfates and chlorides).

\section{Chloride-induced corrosion process of iron - a thermodynamic analysis}

Equilibrium calculations were performed for the Fe-[O-Cl-S-(Na,K)] system based on: - thermodynamic properties of pure components (i) taking part in the reaction and described by chemical potential $\Delta \mu_{i}^{0}=a+b T+c T \ln (T)$, the relation was determined based on molar heat capacity function $\left(\mathrm{C}_{\mathrm{p}}\right)$, 
- the Gibbs free energy change $\Delta G_{T}^{0}=-R T \ln K$,

- parametric equations, which determine composition change from initial to equilibrium $x_{i}^{0} \rightarrow$ $x_{i}$, the gas phase composition changes along a linear function of parameter $\tau \in R$, a vector parallel to the function: $x_{i}=x_{i}^{0}+\tau \cos \left(\alpha_{i}\right)(i=1, \ldots, s)$ determines a transformation of the reactants (i) from initial to final (equilibrium) state [26, 27, 28, 29],

- conditions for thermodynamic equilibrium and diffusive equilibrium,

- thermodynamic databases [30,31] and a numerical computing environment - MATLAB.

The corrosion process model reactions $(\mathrm{j})$ used in the thermodynamic analysis of [O-Cl-S$(\mathrm{Na}, \mathrm{K})]$ system are presented in Tab. 1 .

Table 1. Gas phase corrosion process of iron model reactions in [O-Cl-S-(Na,K)] system.

\begin{tabular}{|c|c|c|}
\hline $\mathrm{j}$ & reaction & $\ln \mathrm{K}$ \\
\hline 1 & $2 \mathrm{HCl}+0.5 \mathrm{O}_{2} \leftrightarrow \mathrm{Cl}_{2}+\mathrm{H}_{2} \mathrm{O}$ & 0.6225 \\
\hline 2 & $2 \mathrm{NaCl}_{(g)}+\mathrm{Fe}_{2} \mathrm{O}_{3}+0.5 \mathrm{O}_{2} \leftrightarrow \mathrm{Na}_{2} \mathrm{Fe}_{2} \mathrm{O}_{4}+\mathrm{Cl}_{2}$ & 1.4096 \\
\hline 3 & $2 \mathrm{KCl}_{(s)}+\mathrm{Fe}_{2} \mathrm{O}_{3}+0.5 \mathrm{O}_{2} \leftrightarrow \mathrm{K}_{2} \mathrm{Fe}_{2} \mathrm{O}_{4}+\mathrm{Cl}_{2}$ & 122 \\
\hline 4 & $2 \mathrm{NaCl}_{(g)}+\mathrm{SO}_{2}+\mathrm{O}_{2} \leftrightarrow \mathrm{Na}_{2} \mathrm{SO}_{4(s)}+\mathrm{Cl}_{2}$ & 43.864 \\
\hline 5 & $2 \mathrm{KCl}_{(g)}+\mathrm{SO}_{2}+\mathrm{O}_{2} \leftrightarrow \mathrm{K}_{2} \mathrm{SO}_{4(s)}+\mathrm{Cl}_{2}$ & 44.501 \\
\hline 6 & $2 \mathrm{NaOH}_{(c)}+\mathrm{Fe}_{2} \mathrm{O}_{3}=\mathrm{Na}_{2} \mathrm{Fe}_{2} \mathrm{O}_{4}+\mathrm{H}_{2} \mathrm{O}$ & 8.544 \\
\hline 7 & $2 \mathrm{NaCl}_{(g)}+\mathrm{H}_{2} \mathrm{O}+0.5 \mathrm{O}_{2}=2 \mathrm{NaOH}_{(c)}+\mathrm{Cl}_{2}$, & $-10,2072$ \\
\hline 8 & $2 \mathrm{NaCl}_{(g)}+\mathrm{H}_{2} \mathrm{O}+0.5 \mathrm{O}_{2}=2 \mathrm{NaOH}_{(g)}+\mathrm{Cl}_{2}$, & -42.642 \\
\hline
\end{tabular}

Phase stability of iron chlorides, oxides and pure iron depends on chlorine and oxygen concentration in the gas phase. A phase stability diagram for $[\mathrm{Fe}-\mathrm{O}-\mathrm{Cl}]$ system at $\mathrm{T}=800 \mathrm{~K}$ is presented in Fig. 2. Low partial pressures of chlorine and oxygen $\left(P_{\mathrm{Cl}_{2}}=10^{-16}\right.$ [atm.], $P_{\mathrm{O}_{2}}=$ $10^{-27}$ [atm.]) protect iron against chloride and oxide corrosion. At partial pressures of oxygen $P_{O_{2}}=10^{-8}$ [atm.] and chlorine $P_{C l_{2}}=10^{-3}$ [atm.], formation of chloride phase in contact with pure hematite $\left(\mathrm{FeCl}_{2} / \mathrm{Fe}_{2} \mathrm{O}_{3}\right)$ might be observed. According to reaction (1), steam and chlorine formation in the gas phase is determined by $\mathrm{HCl}$ and oxygen concentration in the exhaust gas. The actual composition of the gas phase was defined by a set of parametric equations [26-29]. The calculations were carried out for initial concentrations of oxygen $\left(x_{O_{2}}^{0}=5 \cdot 10^{-2}\right)$, hydrochloric acid $\left(x_{H C l}^{0}=3 \cdot 10^{-3}\right)$ and nitrogen $\left(x_{N_{2}}^{0}=0.947\right)$, which correspond to the experimental conditions in [3]. Total pressure of the system was assumed to be $1 \mathrm{~atm}$. ( $\left.\mathrm{P}_{\text {tot }}=1 \mathrm{~atm}\right)$. Assuming constant water vapor concentration $\mathrm{P}_{\mathrm{H} 2 \mathrm{O}}=$ const., the equilibrium concentrations $\mathrm{Cl}_{2}=\mathrm{f}\left(\mathrm{O}_{2}\right)$ tend to gaseous chloride corrosion with a decrease of moisture in the flue gas. According to an active oxidation model, an activation of chlorine can be observed. [3]

In a full-scale biomass firing units and in laboratory experiments carried out in the conditions similar to the biomass combustion, the oxygen content is around $5 \%$ and $\mathrm{HCl}$ is $500-3000$ ppm. In such conditions, iron (III) oxide $-\mathrm{Fe}_{2} \mathrm{O}_{3}$ is the stable phase and the oxide corrosion is the main process. 


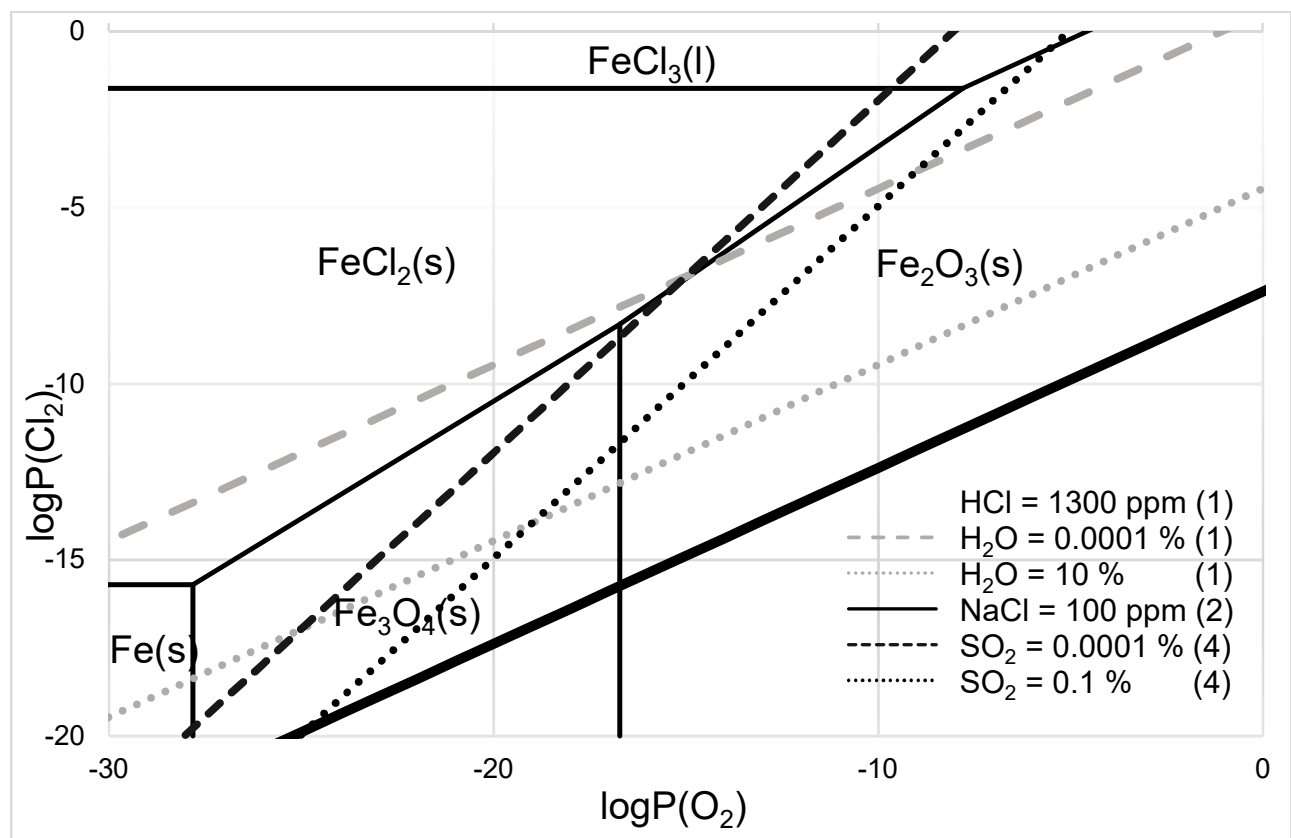

Fig. 2. Phase stability diagram of the system $\mathrm{Fe}-\mathrm{O}-\mathrm{Cl}$ at $\mathrm{T}=800 \mathrm{~K}$

\subsection{The actual composition of the gas phase}

The equilibrium composition $x_{i}$ of the gas phase depends on oxygen initial concentration $\left(x_{O_{2}}^{0}\right.$ ) according to reaction (1). At $800 \mathrm{~K}$, the equilibrium compositions $x_{i}$ are shown in Tab.2 and in Fig.3. When the initial oxygen concentration in the combustion gas is reduced, moisture content, oxygen and chlorine equilibrium concentrations decrease. Under reducing conditions the gas phase composition tends to the chloride corrosion process.

Table 2. Deacon reaction gas phase compositions at $\mathrm{T}=800 \mathrm{~K}$, according to parametric equation calculations [26-29].

\begin{tabular}{|c|c|c|c|c|c|}
\hline \multicolumn{2}{|c|}{$x_{i}^{o}$} & \multicolumn{4}{c|}{$l \mid$} \\
\hline $\mathrm{HCl}$ & $\mathrm{O}_{2}$ & $\mathrm{O}_{2}$ & $\mathrm{Cl}_{2}$ & $\mathrm{H}_{2} \mathrm{O}$ & $\mathrm{HCl}$ \\
\hline \multirow{4}{*}{0.003} & 0.05 & $-1,3045$ & $-3,0732$ & $-3,0732$ & $-2,8822$ \\
\cline { 2 - 6 } & 0.01 & $-2,0151$ & $-3,1599$ & $-3,1599$ & $-2,7913$ \\
\cline { 2 - 6 } & 0.001 & $-3,1158$ & $-3,3292$ & $-3,3292$ & $-2,6854$ \\
\cline { 2 - 6 } & 0.0001 & $-5,1447$ & $-3,7312$ & $-3,7312$ & $-2,5802$ \\
\cline { 2 - 6 } & 0.00001 & $-9,2218$ & $-4,6990$ & $-4,6990$ & $-2,5287$ \\
\cline { 2 - 6 } & 0.000001 & $-13,2427$ & $-5,6990$ & $-5,6990$ & $-2,5235$ \\
\hline
\end{tabular}




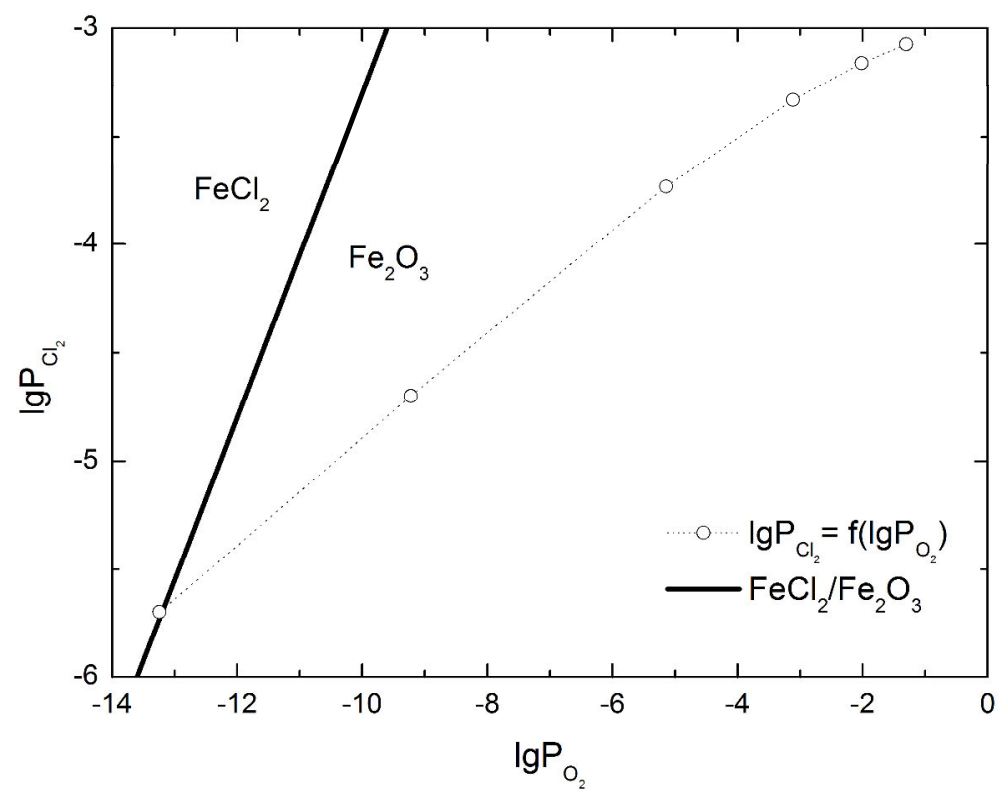

Fig. 3. Phase stability diagram of the system $\mathrm{Fe}-\mathrm{O}-\mathrm{Cl}$ at $\mathrm{T}=800 \mathrm{~K}$ with the equilibrium compositions of the Deacon reaction $\left(x_{\mathrm{HCl}}^{0}=0.003\right.$ i $\left.x_{\mathrm{O}_{2}}^{0}=0.05-10^{-6}\right)$

\subsection{The role of alkali metal chlorides in corrosion process of iron}

When $\mathrm{NaCl}_{(\mathrm{g})}$ is added under oxidizing conditions, a new [Fe-O-Cl-Na] system is introduced. According to reaction (2), hematite reacts with $\mathrm{NaCl}_{(\mathrm{g})}$ and solid $2 \mathrm{NaFeO}_{2}$ is formed. [9] Assuming, the activity of solid phase components equal to unity $\left(a_{2 \mathrm{NaFeO}_{2}}=a_{\mathrm{Fe}_{2} \mathrm{O}_{3}}=1\right)$, for $\mathrm{P}_{\mathrm{NaCl}}=100 \mathrm{ppm}$, a relation $\lg \mathrm{Cl}_{2}=\left(\mathrm{l} l \mathrm{O}_{2}\right)$ is presented in Fig. 2. In these conditions, the corrosion proceed within the oxide corrosion range. Solid $2 \mathrm{NaFeO}_{2}$ formed on the hematite surface can be destructive for passive oxide layer $\left(\mathrm{Fe}_{2} \mathrm{O}_{3}\right)$. However, according to reaction (1) and (2), $2 \mathrm{NaFeO}_{2}$ formation is limited by water vapor concentration in the combustion gas. At $800 \mathrm{~K}, 45 \mathrm{~atm}$. of $\mathrm{H}_{2} \mathrm{O}$ in the gas phase will be required for formation of separate phases $2 \mathrm{NaFeO}_{2}-\mathrm{Fe}_{2} \mathrm{O}_{3}$. Although, the mechanism of $2 \mathrm{KFeO}_{2}$ formation is different. First, $\mathrm{KCl}_{(\mathrm{g})}$ condensate on the oxide scale and next $\mathrm{KCl}_{(\mathrm{s})}$ reacts with hematite (3). The steam partial pressure needed for the reaction to proceed is $10^{-50}$ [atm] only. Therefore, $2 \mathrm{KFeO}_{2}$ formation in biomass combustion atmosphere is not limited by water vapor concentration. According to (9), the decrease of hematite activity will intensify the oxide corrosion process. The activity of $\mathrm{Fe}_{2} \mathrm{O}_{3}$ will decrease with water vapor concentration increase and dissolution of $2(\mathrm{Na}, \mathrm{K}) \mathrm{FeO}_{2}$ in low melting eutectic mixtures:

$$
a_{\mathrm{Fe}_{2} \mathrm{O}_{3}}=\frac{K_{1}}{K_{(2,3)}}\left(\frac{P_{\mathrm{HCl}}}{P_{\mathrm{NaCl}}}\right)^{2} \frac{a_{2(\mathrm{Na}, \mathrm{K}) \mathrm{FeQ}}}{P_{\mathrm{H}_{2} \mathrm{O}}}
$$

The reaction mechanism is different when fly ash rich in chlorides $\left(11 \mathrm{PbCl}_{2}-50 \mathrm{KCl}-\right.$ $39 \mathrm{ZnCl}_{2}$ wt. $\%, \mathrm{~T}_{\mathrm{m}}=821 \mathrm{~K}$ ) is deposited on heat exchanging surfaces. The oxide corrosion process is intensified by steam concentration and anticorrosive properties of iron and lowalloy steels are decreased [15].

The corrosion process of iron in atmosphere rich in chlorine and water vapor has a two way mechanism. The increase of steam concentration and low melting ash components formation in the deposits enhance the oxide corrosion attack. When the steam concentration decreases, a corrosive agent $-\mathrm{Cl}_{2}$ is activated and chloride corrosion rate increases. The dissolution of 
$2(\mathrm{Na}, \mathrm{K}) \mathrm{FeO}_{2}$ in low melting eutectic mixtures will decrease the activity $\left(a_{2(\mathrm{Na}, \mathrm{K}) \mathrm{FeO}_{2}}<1\right)$ and the oxide corrosion process will be intensified. In biomass-fired boilers, low melting eutectic mixtures are formed in the reaction of $\mathrm{NaCl}_{(\mathrm{g})}$ and $\mathrm{KCl}_{(\mathrm{g})}$ condensed on the oxide scale with other fly ash components.

\subsection{Condensation of alkali metal chlorides}

At equilibrium, in multiphase multicomponent system any two phases of the same compound in contact with each other must have the same chemical potential. Therefore, at equilibrium for $\mathrm{NaCl}$ and $\mathrm{KCl}$ in different phases the relation $\mu_{i(s)}=\mu_{i(g)}(i=\mathrm{NaCl}, \mathrm{KCl})$ is true. At $\mathrm{T}$ $=800 \mathrm{~K}$ the vapor pressures of pure $(\mathrm{Na}, \mathrm{K}) \mathrm{Cl}$ in equilibrium with their solid phase are presented in Table 3.

$$
R T \ln P_{i}^{0}=\mu_{i(s)}^{0}-\mu_{i(g)}^{0}
$$

where: $\mathrm{R}=8.314[\mathrm{~J} / \mathrm{mol} \mathrm{K}], \mathrm{T}-$ temperature in $[\mathrm{K}], P_{i}^{0}$ equilibrium vapour pressure of ,i” component in $[\mathrm{atm}](\mathrm{i}=\mathrm{NaCl}, \mathrm{KCl}), \mu_{i(s)}^{0}, \mu_{i(g)}^{0}\left[\frac{J}{m o l}\right]$ - chemical potentials of ,i” component in solid and gas phase.

Table 3. The equilibrium vapor pressures of $\mathrm{NaCl}$ and $\mathrm{KCl}$ at $800 \mathrm{~K}$.

\begin{tabular}{|c|c|c|}
\hline \multirow{2}{*}{$\mathrm{i}$} & \multicolumn{2}{|c|}{$\mathrm{T}=800 \mathrm{~K}$} \\
\cline { 2 - 3 } & $\ln P_{i}^{0}$ & $P_{i}^{0}[p p m]$ \\
\hline $\mathrm{NaCl}$ & -15.115 & 0.273 \\
\hline $\mathrm{KCl}$ & -15.234 & 0.242 \\
\hline
\end{tabular}

In biomass-firing units and waste incineration power plants, potassium and sodium chlorides emission varies from 5 to $120 \mathrm{ppm}$. At $\mathrm{T}=800 \mathrm{~K}$, the $\mathrm{KCl} / \mathrm{NaCl}$ equilibrium vapor pressures (Tab. 3) are lower than the partial pressure of the chlorides in the combustion gases. Therefore the alkali metal chlorides condensate on heat exchanging surfaces and can form low melting eutectic mixtures with other fly ash components.

\subsection{The role of sodium hydroxide in corrosion process of iron}

The theory of corrosion attack by condensed $\mathrm{NaOH}_{(\mathrm{c})}$ is not is thermodynamically favored. At $\mathrm{T}=800 \mathrm{~K}$ and in the combustion atmosphere $P_{\mathrm{HCl}}=1000 \mathrm{ppm}, P_{\mathrm{NaCl}}=$ $100 \mathrm{ppm}, P_{\mathrm{H}_{2} \mathrm{O}}=10 \%$, partial pressure of $\mathrm{NaOH}_{(\mathrm{g})}$ from reaction (8) and (1) $\left(\lg P_{\mathrm{NaOH}_{(g)}}=\right.$ -11.122) is lower than equilibrium pressure of the evaporation process $\mathrm{NaOH}_{(c)} \rightarrow$

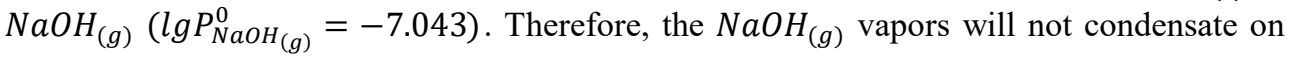
the heat exchanging surfaces. Formation of $\mathrm{NaOH}_{(\mathrm{c})}$ from reactions (1) and (7) is limited by moisture content in the flue gas. Assuming liquid oxide phase as an ideal mixture $\left(a_{i} \cong\right.$ $\left.x_{i}, i=\mathrm{NaOH}, \mathrm{Fe}_{2} \mathrm{O}_{3}, 2 \mathrm{NaFeO}_{2}\right)$, the $\mathrm{NaOH}_{(\mathrm{c})}$ concentration $-x_{\mathrm{NaOH}_{(c)}}$ is $1 / 10$ of the equilibrium concentration form the reaction (6).

\subsection{The role of sulfur dioxide in corrosion process of iron}

When sulfur dioxide is present in the combustion atmosphere, alkali sulfates are formed according to reactions (4 and 5). Assuming constant conditions: $\mathrm{P}_{\mathrm{NaCl}}=100$ ppm., $P_{\mathrm{SO}_{2}}=$ const. and $a_{\mathrm{Na}_{2} \mathrm{SO}_{4}}=1$, the gas phase compositions $\lg P_{\mathrm{Cl}_{2}}=f\left(\lg \mathrm{P}_{\mathrm{O}_{2}}\right)$ proceed in the oxide corrosion range (Fig. 2). With an increase of $\mathrm{SO}_{2}$ concentration, gas phase equilibrium concentrations $\mathrm{Cl}_{2}=\mathrm{f}\left(\mathrm{O}_{2}\right)$ tends to gaseous chloride corrosion. Therefore, $\mathrm{SO}_{2}$ presence in gas 
phase leads to additional chlorine generation and activation of chloride corrosion process according to an active oxidation model.

Sulfur dioxide in the combustion gas affect also the condensation of $\mathrm{NaCl}$ and $\mathrm{KCl}$ vapors. The condensed alkali metal chlorides can react with other fly ash components and form eutectics of low melting point: $\mathrm{NaCl}-\mathrm{KCl}-\mathrm{MeCl}_{2}$. The equilibrium pressure of the chloride $\mathrm{NaCl}_{(\mathrm{g})}$ or $\mathrm{KCl}_{(\mathrm{g})}$ depends on the gas phase equilibrium composition, according to reactions (1) and $(4,5)$ :

$$
\operatorname{llP}_{(\mathrm{Na}, \mathrm{K}) \mathrm{Cl}}=\operatorname{lrP}_{\mathrm{HCl}}+0.5\left(\mathrm{lrK}_{1} \mathrm{trK} \quad\left(4,5 \mathrm{HrP}_{\mathrm{SO}_{2}} \mathrm{trP} \mathrm{H}_{2} \mathrm{O}\right) 0.25 \mathrm{lrP}_{\mathrm{O}_{2}}\right.
$$

In a steady-state combustion process conditions: $P_{\mathrm{HCl}}=1300 \mathrm{ppm}, P_{\mathrm{SO}_{2}}=100 \mathrm{ppm}$, $P_{\mathrm{H}_{2} \mathrm{O}}=10^{-1} \mathrm{~atm}$, the equilibrium pressure of the chlorides $\mathrm{NaCl}_{(\mathrm{g})}$ and $\mathrm{KCl}_{(\mathrm{g})}(\mathrm{T}=800 \mathrm{~K})$ depends on oxygen partial pressure, according to relations :

$$
\begin{gathered}
\lg P_{\mathrm{NaCl}}=-9.7763-0.1086 \lg P_{\mathrm{O}_{2}} \\
\lg P_{\mathrm{KCl}}=-9.9144-0.1086 \lg P_{\mathrm{O}_{2}}
\end{gathered}
$$

In oxidizing combustion conditions, alkali sulfates formation according to $(4,5)$ decrease $(\mathrm{Na} . \mathrm{K}) \mathrm{Cl}$ vapor pressure below the equilibrium value needed for the condensation process $(\mathrm{Na}, \mathrm{K}) \mathrm{Cl}_{(\mathrm{g})} \rightarrow(\mathrm{Na}, \mathrm{K}) \mathrm{Cl}_{(\mathrm{s})}$ (Fig. 4).

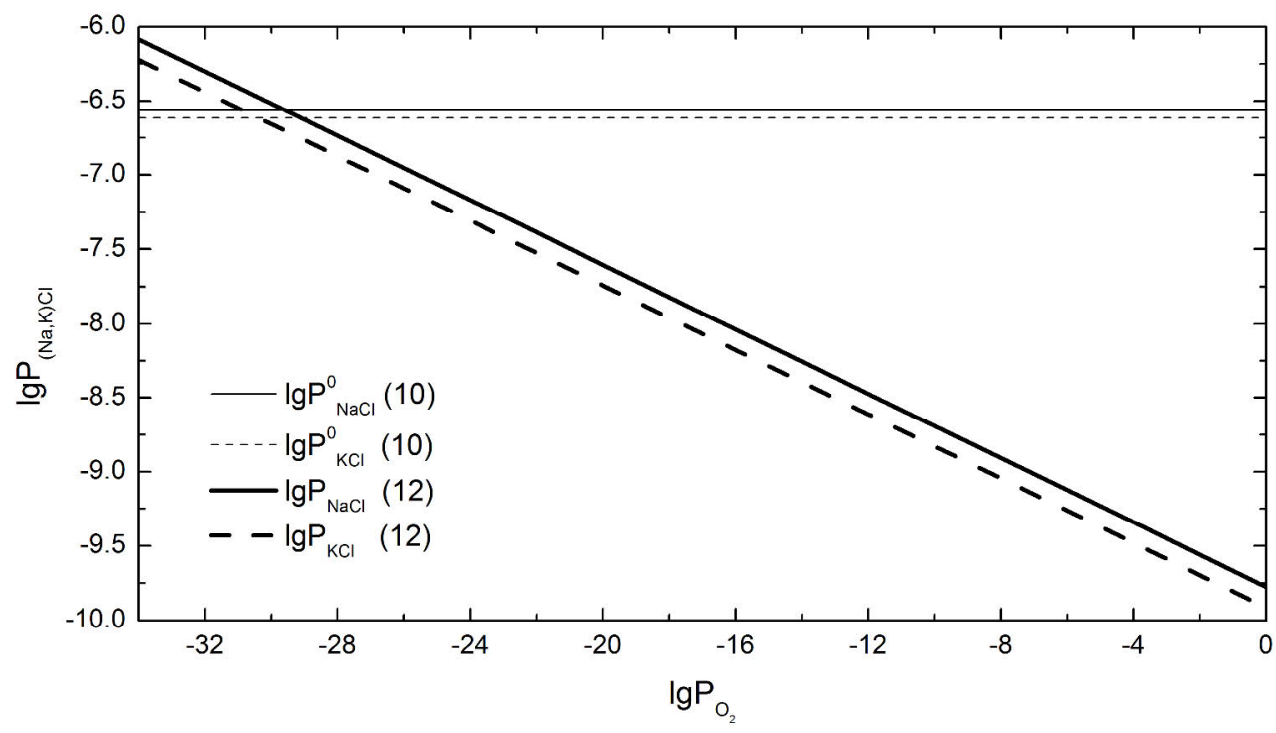

Fig. 4. Vapor pressures of alkali chlorides: $\mathrm{NaCl}$ and $\mathrm{KCl}$ in the combustion gas, at $\mathrm{T}=800 \mathrm{~K}$.

Sulfur dioxide inhibits the condensation of alkali chlorides in the combustion gases. Therefore, the risk of low melting ash components formation and ash deposits fusion or partial fusion is decreased. The more stable sulfates are formed in the deposits. The solubility of hematite in fused chlorides is limited and the oxide corrosion rate is reduced. However, in a certain temperature range alkali sulfates and other complex salts mixtures can accelerate corrosion attack by a so-called ,hot corrosion” process. 


\section{Conclusions}

Several conclusions come from the presented analysis of high-temperature corrosion in $\mathrm{Fe}$ [O-Cl-S-(Na,K)] system. At $\mathrm{T}=800 \mathrm{~K}$ in a oxidizing atmosphere $\left(\mathrm{O}_{2}-5 \%, \mathrm{Cl}_{2}<1300 \mathrm{ppm}\right)$, chloride corrosion process mechanism is not thermodynamically favored. Concentration of $\mathrm{HCl}$ and oxygen determine water vapor formation. In steady-state conditions, equilibrium concentrations $\mathrm{Cl}_{2}=\mathrm{f}\left(\mathrm{O}_{2}\right)$ tend to gaseous chloride corrosion with a decrease of moisture in the gas phase and the activation of chlorine according to an active oxidation model can be observed. When deposits rich in chlorides $\left(\mathrm{NaCl} / \mathrm{KCl} / \mathrm{MeCl}_{2}\right)$ are introduced to the system, the influence of the water vapor concentration on chloride corrosion process is minor and the steam accelerates the rate of the oxide corrosion. When chlorine compounds and water vapor are present in the combustion gas the corrosion process of iron has a two-way mechanism. The increase of the water vapor content and formation of low melting components in the deposits accelerates the corrosion attack in the oxide area. A decrease of $\mathrm{H}_{2} \mathrm{O}$ partial pressure in the flue gas activates chlorine towards gaseous chloride corrosion. In reducing atmosphere the water vapor concentration in the system decreases. Low steam concentrations promotes gaseous chloride corrosion. Condensation of alkali chlorides is one of the mechanisms of low melting ash deposits components formation on heat exchanging surfaces. At $\mathrm{T}=800 \mathrm{~K}$, partial pressures of potassium and sodium chlorides are higher than vapor pressures of gaseous chlorides in equilibrium with the pure chlorides in the solid phase. Condensed alkali chlorides can form eutectics of low melting point and the oxide corrosion process will be accelerated $\left(a_{\mathrm{Fe}_{2} \mathrm{O}_{3}}<1\right)$.

The theory of corrosion attack by condensed $\mathrm{NaOH}_{(\mathrm{c})}$ is not is thermodynamically favored. Sulfur dioxide in gas phase leads to additional chlorine generation and activation of chloride corrosion process according to an active oxidation model. In oxidizing combustion conditions, alkali sulfate formation decreases the alkali chlorides vapor pressure below the equilibrium value needed for the condensation process $(\mathrm{Na}, \mathrm{K}) \mathrm{Cl}(\mathrm{g}) \rightarrow(\mathrm{Na}, \mathrm{K}) \mathrm{Cl}_{(\mathrm{s})}$. Therefore, sulfur dioxide inhibits the condensation of alkali chlorides in the combustion gas and the risk of low melting ash components formation and ash deposits fusion or partial fusion is decreased. The more stable sulfates are formed in the deposits. The solubility of hematite in fused chlorides is limited and the oxide corrosion rate is reduced. In a certain temperature range alkali sulfates and other complex salts mixtures can accelerate corrosion attack by a so-called „hot corrosion” process.

Presented conclusions can be used for combustion processes optimization as well as in interpretation of steel chloride-induced corrosion experiments.

The present work was supported by the Polish Ministry of Science (Grant AGH No. 11.11.210.312)

\section{References}

1. European Commission, Renewable energy progress report (Brussels, 2015)

2. Final meeting of the technical working group (TWG), for the review of the BAT reference document for large combustion plants (LCP BREF), final meeting, background paper (BP) (Seville, 2015)

3. P.Viklund, Superheater corrosion in biomass and waste fired boilers. Characterization, causes and prevention of chlorine-induced corrosion (Sweden, Division of Surface and Corrosion Science, Department of Chemistry, School of Chemical Science and Engineering, 2013)

4. M. Pronobis, Modernizacja kotłów energetycznych (Wydawnictwo NaukowoTechniczne, Warszawa 2002)

5. T. Hardy, W, Kordylewski, K. Mościcki, Arch. Spal., 9, 181-195 (2009) 
6. M. Spiegel, Beeinflussung der Korrosionsgeschwindigkeit von den Verhaltnissen im rohrwandnahen Bereich bei der HT-Chlor-Korrosion. Vortag VDIWissensforum „Belage und Korrosion“, 14.06.2005 in Dampferzeugerkorrosion, M. Born (Freiberg, SAXONIA Standortentwicklungs-und-Verwaltungsgesellschaft $\mathrm{mbH}, 2005$ )

7. J. R. Nicholls, R. Newton, N. J. Simms, J. F Norton, Mater. High Temp., 20 (2), 93-108 (2003)

8. A. Zahs, M. Spiegel, H. J. Grabke, Mater. Sci. Eng., 50, 561-578 (1999)

9. H. J. Grabke, E. Reese, M. Spiegel, Corro. Sci., 37, 7, 1023-1043 (1995)

10. M.A. Uusitalo, P.M.J. Vouoristo, T.A. Mäntylä, Corro. Sci., 46, 1311-1331 (2004)

11. K. Salmenoja, M. Hupa, R. Backman, Laboratory Studies on the Influence of Gaseous $\mathrm{HCl}$ on Fireside Corrosion of Superheaters in Impact of Mineral Impurities in Solid Fuel Combustion, edited by R. P. Gupta, T. F. Wall, L. Baxter (Springer US, New York, 1999)

12. D. Bramhoff u.a.: Einfluss von $\mathrm{HCl}$ und $\mathrm{Cl}_{2}$ auf die Hochtemperaturkorrosion des 2,25Cr1Mo-Stahls in Atmospharen mit hohen Sauerstoffdrucken. Werkstoffe und Korrosion in Dampferzeugerkorrosion, M. Born (Freiberg, SAXONIA Standortentwicklungs-und-Verwaltungsgesellschaft $\mathrm{mbH}, 2005$ )

13. M. Spiegel,, Mater. Corro., 50, 373-393 (1999)

14. M.A. Uusitalo, P.M.J. Vuoristo, T.A. Mantyla, Mater. Sci. Eng., 346, 168-177 (2003)

15. M. Sanchez Pasten, M. Spiegel, Mater. Corro., 57, 2, 192-192 (2006)

16. K. Zhang, Y. Niu, C. Zeng, W. Wu, J. Mater. Sci. Technol., 20, 2, 213-216 (2004)

17. B. J. Skrifvars, M. Westén-Karlsson, M. Hupa, K. Salmenoja, Corro. Sci., 52, 1011-1019 (2010)

18. B. J. Skrifvars, R. Backman, M. Hupa, K. Salmenoja, E. Vakkilainen, Corro. Sci., 50, 1274-1282 (2008)

19. Y. S. Li, Y. Niu, W.T. Wu, Mater. Sci. Eng., A345, 64, 64-71 (2003)

20. J. Waltl, N. Rechberger, VGB PowerTech, 3, 48-52 (2006)

21. M. Aho, E. Ferrer, Fuel, 84, 201-212 (2005)

22. R.W. Bryers, Factors critically affecting fireside deposits in steam generators in Impact of Mineral Impurities in Solid Fuel Combustion, edited by R. P. Gupta, T. F. Wall, L. Baxter (Springer US, New York, 1999)

23. S.C. Srivastava, K.M. Godiwalla, M.K. Banerjee, J. Mater Sci, 32, 835-849 (1997)

24. T. Blomberg, Mater. Corro., 57, 170-175 (2006)

25. M. Born, VGB PowerTech, 5, 107-111 (2005)

26. W. Ptak, M. Sukiennik, Bulletin de l'Academie Polonaise des Sciences. Serie des sciences techniques, 17, 21-25 (1969)

27. W. Ptak, M. Sukienni, R. Olesinski, R. Kaczmarczyk, Arch. Metall., 32, 355-362 (1987)

28. R. Kaczmarczyk, S. Gurgul, Arch. Metall. Mater., 59, 4, 1379-1383 (2014)

29. R. Kaczmarczyk, S. Gurgul S, Arch. Metall. Mater., 59, 1, 145-148 (2014)

30. O. Knacke, O. Kubaschewski, K. Hesselmann, Thermochemical Properties of Inorganic Substances (Berlin, Springer, 1991)

31. Outokumpu HSC Chemistry, Chemical Reaction and Equilibrium Software, (Outokumpu Research Oy, Finland, 2002) ISBN 952-9507-08-9. 